\title{
Forbes and Rigobon's Method of Contagion Analysis with Endogenously Defined Crisis Periods - an Application to Some of Eurozone's Stock Markets
}

\section{Silvo Dajeman}

\author{
University of Maribor \\ Razlagova 14, 2000 Maribor, Slovenia \\ e-mail: silvo.dajcman@uni-mb.si
}

cross $^{\text {ref }}$ http://dx.doi.org/10.5755/j01.ee.24.4.5419

\begin{abstract}
The existent literature provides numerous definitions and statistical methods for analysis of contagion in the financial markets. The definition of shift contagion of Forbes and Rigobon (2001) and their adjusted correlation analysis (Forbes and Rigobon, 2002) have gained a lot of attention but the later faces the problem of ad hoc determination of the crisis periods and the issue of volatility adjustment. The aim of this paper is to elaborate the weaknesses of the method of Forbes and Rigobon and to provide a modification of their test that addresses these issues. To achieve this, a moving-window approach of Forbes and Rigobon's (2002) method is proposed, by splitting the moving-windows into two equally sized subwindows. We then apply the modified method to examine whether there was a (shift) contagion in the stock markets of five Eurozone countries (namely France, Germany, Ireland, Italy, and Spain) in the time period from December 2003 to January 2012. We found that shift contagion has played an important role in the propagation of shocks in the investigated stock markets during the crises. The start of the Greece's debt crisis in May 2010 coincided with contagion from the Ireland's, Italy's, and Spain's stock markets to the stock markets of France and Germany. Similar episodes of contagion were indentified around the Middle East financial crisis, at the end of 2006 and the start of 2007. The global financial crisis coincided with contagion from the Italy's and Spain's to the German stock market, while the Ireland's debt crisis with contagion from the Ireland's to the German stock market.

The results of the paper have important implications for the investors in these stock markets. In the mainstream financial literature it has been recognized that international diversification reduces the total risk of a portfolio. This is due to nonperfect positive co-movement between returns of the portfolio assets. Increased co-movement between asset returns, identified during financial market turmoil, therefore can diminish the advantage of internationally diversified investment portfolios. The contagion analysis is also important for financial sector supervisory authorities and the monetary policy as different policy actions may be successful when the increase in co-movement between financial markets is a result of contagion or a result of a change in interdependence between the markets.
\end{abstract}

Keywords: contagion, stock markets, financial crisis, Eurozone debt crisis, global financial crisis.

\section{Introduction}

The existent literature provides many definitions of contagion in financial markets (for an overview see e.g., Forbes \& Rigobon, 2001; Dornbusch et al., 2001; Corsetti et al., 2002; Pericoli \& Sbracia, 2003; Baur \& Lucey, 2009) and a range of statistical procedures for testing its occurrence in financial market ${ }^{1}$. Forbes and Rigobon (2001) provide one of the most commonly accepted definition of contagion, namely the "shift contagion - a shift or change in how shocks spread from one country (or asset class) to another during normal periods (pre-crisis) and how during crisis periods. (Shift) contagion in this paper is defined as a significant positive increase in correlation between (pair-wise observed) stock market returns in the crisis period compared to non-crisis period.

Contagion has to be separated from interdependence. As Forbes and Rigobon (2002) argue, if two markets are traditionally highly correlated, and the correlation does not

\footnotetext{
${ }^{1}$ The most commonly applied tests are the adjusted correlation test of Forbes and Rigobon (2002), the outlier test of Favero and Giavazzi (2002), the co-exceedance test of Bae et al. (2003), and the threshold test of Pesaran and Pick (2004).
}

increase significantly after a shock in one market, then any continued high level of market co-movement suggests strong real linkages between the two economies. In this case there is no contagion but only high interdependence. To separate contagion from interdependence statistically, it is important to identify common factors which impact upon all countries simultaneously (Dungey et al., 2005). A failure to model common factors may result in tests of contagion being biased towards a positive finding of contagion. The test of Forbes and Rigobon (2002) applies a Vector Autoregression (VAR) analysis and uses its residuals in the contagion test. By explicitly including common variables into the model, the Forbes and Rigobon's (2002) test also resolves the issue of modeling structural breaks in the common variables time series (Dungey et al., 2005). Typical common factors are proxied by including into the model variables such as international interest rates and trade, while in the present paper we include also variables of stock market indices and volatility index (index VIX).

There are some issues with the contagion test of Forbes and Rigobon (2002) that deserve reconsideration. The first issue that is weakly addressed is the simultaneity bias and potential weak instrument trade-off. Dungey et 
al., (2005) prove that the test of Forbes and Rigobon (2002) is prone to simultaneity bias if the test is implemented by changing the exogeneity status of the source country.

The next issue is how the crisis period is defined. In the test of Forbes and Rigobon (2002) it is defined subjectively, based on a priori information of the events around the crisis, thus causing a sample selection bias. The third issue with the test of Rigobon and Forbes (2002) that deserves reconsideration, as noted by Cho and Parhizgari (2008), is that it does not adjust volatility continuously and is thus not accepting the stylized fact of time-varying volatility of asset returns. Cho and Parhizgari (2008) suggest the DCC-GARCH (Dynamic Conditional Correlation Generalized Autoregressive Conditional Heteroskedasticity) model of Engle and Sheppard (2001) to correct for this issue.

This paper investigates contagion in the stock markets of five Eurozone countries (namely France, Germany, Ireland, Italy, and Spain) in the period from December 3, 2003 to January 27, 2012. We concentrate on investigating whether there was a contagion from the stock markets that were among the hardest hit by the recent sovereign debt crisis in the Eurozone in the period of 2010-2012 (Ireland, Italy, and Spain) to two major Eurozone stock markets, namely of France and Germany. A modification of Forbes and Rigobon's (2002) test is proposed, based on the movingwindow approach that endogenously determines the dates of the crisis and addresses the issue of volatility adjustment.

\section{Methodology}

Let $r_{1, t}$ and $r_{2 t}$ be the time series of the stock market returns of country 1 (contagion source country) and country 2 (for which we test if there was a contagion from country 1) that have been pre-filtered by a VAR (Vector Autoregressive) model in order to control for serial correlation in stock market returns and any exogenous Eurozone and global shocks (see Forbes and Rigobon (2002) for a similar specification). The VAR specification is:

$$
\begin{aligned}
& r_{j, t}=\sum_{p=1}^{P} \varphi_{p} r_{j, t-p}+\sum_{k=1}^{K} a_{1 k} i_{t-k}^{E Z}+\sum_{k=1}^{K} a_{2 k} y_{t-k}^{U S}+\sum_{k=1}^{K} a_{3 k} r_{t-k}^{U S}+ \\
& +\sum_{k=1}^{K} a_{4 k} i V I X_{t-k}+\varepsilon_{t}
\end{aligned}
$$

where $r_{j, t}$ is a stock market return of the country $j$ $(j=1,2) ; i_{t}^{E Z}$ is a Eurozone money market interest rate (3month EURIBOR), $y_{t}^{U S}$ is a 10-year U.S. Treasury note yield, $r_{t}^{U S}$ a return of the Dow Jones Industrial index, and $V I X_{t}$ a level of the volatility index VIX; $P$ and $K$ are the number of $\operatorname{lags}^{2}$. All variables are calculated as two-day

\footnotetext{
${ }^{2}$ U.S. 10-y Treasury notes yields, Dow Jones Industrial Index returns and the level of VIX index are included as a proxy for global macroeconomic developments and the associated inflation, liquidity, and credit risks (see, e.g., Forbes and Rigobon, 2002; Dungey et al., 2005; Metiu, 2011). The region specific factor that captures local financial market conditions is the
}

rolling-average values in order to control for the fact of different open hours of the markets on which the variables in the model are formed. The returns are in the local currency. Following Forbes and Rigobon (2002), five lags $(P=K=5)$ are utilized in order to control for serial correlation and any within-week variation in trading patterns.

Let $\rho_{y}$ denote the correlation between stock market returns of two countries during the crisis (high volatility) period and $\rho_{x}$ in the pre-crisis (low volatility) period. If there is an increase in the volatility of stock market returns in country $1, \sigma_{y, 1}^{2}>\sigma_{x, 1}^{2}$, without any change to the fundamental relationship between the stock market returns dynamics in the two countries, then $\rho_{y}>\rho_{x}$, thus giving the false appearance of contagion. Forbes and Rigobon (2002) show than unconditional correlation adjusted for this bias is given by (Pericoli \& Sbracia, 2003; Dungey, 2005):

$$
\rho_{a}=\frac{\rho_{y}}{\sqrt{1+\left(\frac{\sigma_{y, 1}^{2}-\sigma_{x, 1}^{2}}{\sigma_{x, 1}^{2}}\right)\left(1-\sigma_{y, 1}^{2}\right)}},
$$

where $\rho_{a}$ is unconditional correlation (i.e. a conditional correlation $\left(\rho_{y}\right)$ scaled by a nonlinear function of the percentage change in volatility in stock market returns in the source country $\left(\frac{\sigma_{y, 1}^{2}-\sigma_{x, 1}^{2}}{\sigma_{x, 1}^{2}}\right)$, i.e. country 1 , over the high and low volatility periods). This adjustment allows for a shift in the volatility of stock market returns of country 1 , whereby $\rho_{a}=\rho_{y}$ if there is no fundamental change in the relationship between the two stock markets.

The null hypothesis of the test of significant change in correlation

$$
H_{0}: \rho_{a}=\rho_{x}
$$

is tested against the alternative

$H_{1}: \rho_{a}>\rho_{x}$.

The hypothesis is tested using Fisher's transformation:

$$
z=\frac{\frac{1}{2} \ln \left(\frac{1+\hat{\rho}_{a}}{1-\hat{\rho}_{a}}\right)-\frac{1}{2} \ln \left(\frac{1+\hat{\rho}_{x}}{1-\hat{\rho}_{x}}\right)}{\sqrt{\frac{1}{T_{y}-3}+\frac{1}{T_{x}-3}}}, z \sim N(0,1) .
$$

The test of contagion consists of testing whether after a pre-specified crisis event, the correlation has increased significantly. The methodology of Forbes and Rigobon (2002) requires an ad hoc classification of crisis and noncrisis periods and thus the results are subject to a sample selection bias (Metiu, 2011). The other most frequently applied tests of contagion (Favero \& Giavazzi's (2002) outlier test, the Pesaran and Pick's (2003) threshold test, and the Bae et al. 's (2003) co-exceedance test) determine the crisis period endogenously by identifying extreme

Eurozone money market rate. As argued by Dungey et al. (2007), the stock markets should not be studied in isolation, as there are interaction effects across different asset classes. 
movements in the data (Dungey et al., 2005) for a review of these methods).

In this paper we use the adjusted Forbes and Rigobon's (2002) methodology whereby the crisis and non-crisis periods do not have to be identified subjectively but rather are identified endogenously by the dynamics of the correlation coefficient. To achieve this, a movingwindow approach of Forbes and Rigobon's (2002) method is proposed, by splitting the moving-window into two equally-sized sub-windows. Using this approach, correlation between the stock market returns at time $t$ is calculated from $w$ observations (where $w$ is the size of the window), centered around time $t$. The window is rolled forward one day at a time, resulting in a time series of correlation. This way we obtain $N-w$ correlation coefficients. The size of the window is 200 trading days ${ }^{3}$. The first half of the moving-window represents the potential pre-crisis period and the second half the potential after crisis period. Contagion is identified if the movingwindow correlation increases by at least 2 standard deviations (this means that the correlation in the second half of the window is significantly higher than in the first half of the window, as indicated by the z-statistics). When the moving-window is moved forward the pre-crisis period in fact becomes a potential crisis period. If both halves of the windows are in the increased correlation period, then the correlation will not change significantly. However, if in the second half of the window the correlation is significantly smaller than in the first half of the movingwindow this reduction in the correlation is interpreted as a sign of the end of a contagion period.

\section{Data and empirical results}

Contagion between stock market returns of France, Germany, Ireland, Italy, and Spain is analyzed for the period from December 3, 2003 to January 27, 2012. The stock market returns are calculated from the main national stock indices as the differences in the logarithms of the daily closing prices of the indices. The stock indices included are: the CAC40 (for France), DAX (for Germany), ISEQ (for Ireland), FTSE-MIB (for Italy), and IBEX35 (for Spain). Days with no trading in any of the observed market were left out. The data for stock indices re obtained from Yahoo! Finance. Table 1 presents some descriptive statistics of the data.

All series display significant leptokurtic behavior as evidenced by the large kurtosis with respect to the Gaussian distribution. The Jarque-Bera test rejected the hypothesis of normally distributed time series. We also tested for stationarity of time series by the Augmented Dickey-Fuller (ADF) test and Kwiatkowski-PhillipsSchmidt-Shin (KPSS) tests and the results (not reported here, but obtainable form the author) lead to conclusion of no unit root in the return series.

\footnotetext{
3 The size of the window has to be long enough to obtain enough observations in each half of the window (i.e. 100 observations/days) to estimate correlation in the half-windows. We tried also with longer windows (of 400 days) and the results did not change considerably from the point of view of the identified time of contagion between the sovereign markets. 200-days moving windows are often used in analyzing stock markets (Dajcman et al., 2012; Ranta, 2010).
}

Table 2 reports Pearson's correlation coefficients for pair-wise observed stock indices. Notably, the correlation between the stock markets of France and Germany was the highest throughout the observed period, followed by the stock markets of France and Italy.

Results of the contagion analysis are presented graphically in Figures 1 through 3 . Figure 1 presents the plots of Forbes-Rigobon's adjusted moving-window correlation coefficients and the corresponding movingwindow z-statistics for stock market pairs France-Ireland, France-Italy, and France-Spain. The second country in the stock market pair is taken as the source country of contagion. For comparison purpose also the Pearson's moving-window correlation coefficients are drawn in the same plots. Figure 2 presents the same plots for the stock market pairs Germany-Ireland, Germany-Italy, and Germany-Spain, while Figure 3 provides the plots for the stock market pair France-Germany.

As evident from all three Figures, the correlation of stock market returns is time-varying, with significant increases as well as significant drops. Notably, the correlation between pair-wise observed stock markets increased from the start of 2004 until the start of 2007, then dropped and again rose in the period from the mid 2008 until the second half of 2009 when the concern about the sustainability of Greece's sovereign debt caused an increase in risk aversion in the Eurozone's stock markets.

As in this paper a contagion is defined as a significant positive increase in correlation between (pair-wise observed) stock market returns in the crisis period compared to non-crisis period, we are interested only in significant increases of correlation. As indicated by the zstatistics, there was a contagion from Ireland's to France's stock market in the second half of 2005 and in the second half of 2009 (Figure 1). Apparently, the correlation increased significantly a few trading days before the culmination of the Middle East financial crisis (the start of May 2006 is taken as the time of the outbreak of the crisis) and Greece's debt crisis. There was no contagion from Ireland's stock market to France's stock market around the culmination of the global financial crisis (September 16, 2008, the collapse of Lehman Brothers is taken as the time point of culmination of the global financial crisis). The contagion from Spain's stock market to France's stock market also took place before the start of the Middle East financial market crisis, and Greece's debt crisis. Another contagion from the stock market of Spain to the stock market of France took place in the second half of $2006^{4}$.

Contagion from Italy's to France's stock market was identified at the start of 2007 and before the start of Greece's debt crisis. Clearly, the outbreak of the Eurozone's debt crisis that started with Greece's sovereign debt problems caused the most significant increase in correlation between the observed stock markets. Other major financial market disruptions (the global financial crisis, Ireland's debt crisis, and Italy's debt crisis) cannot be associated with contagion from Ireland's, Italy's, and Spain's stock markets to the stock market of France.

\footnotetext{
${ }^{4}$ Note that due to the construction characteristics of the moving-window correlation coefficients, the effect of the event should start to show up in the graph 100 days before the actual time of the event.
} 
Descriptive statistics for stock index return time series

\begin{tabular}{|c|c|c|c|c|c|c|c|}
\hline $\begin{array}{c}\text { Stock index (stock } \\
\text { market) }\end{array}$ & Min & $\operatorname{Max}$ & Mean & Std. deviation & Skewness & Kurtosis & $\begin{array}{c}\text { Jarque-Bera } \\
\text { statistics }\end{array}$ \\
\hline CAC40 (France) & -0.0947 & 0.1059 & -0.000026 & 0.01577 & 0.1642 & 10.4452 & $4,440.75 * * *$ \\
\hline DAX (Germany) & -0.0743 & 0.108 & 0.0002778 & 0.0153 & 0.1162 & 9.4645 & $3,345.76^{* * *}$ \\
\hline ISEQ (Ireland) & -0.1396 & 0.09733 & -0.000241 & 0.01726 & -0.5573 & 9.8403 & $3,840.51 * * *$ \\
\hline FTSEMIB (Italy) & -0.0997 & 0.1087 & -0.000284 & 0.01618 & -0.1569 & 9.6681 & $3,563.07 * * *$ \\
\hline IBEX35 (Spain) & -0.1160 & 0.1348 & -0.000084 & 0.01601 & 0.0099 & 12.0721 & $6,580.83 * * *$ \\
\hline
\end{tabular}

Notes: The Jarque-Bera statistics: *** indicate that the null hypothesis (of normal distribution) is rejected at a $1 \%$ significance level. Source: Own calculations.

Table 2

Pearson's correlation between the stock market returns of investigated Eurozone countries

\begin{tabular}{|l|r|r|r|r|r|}
\hline & CAC40 (France) & DAX /Germany) & ISEQ (Ireland) & FTSEMIB (Italy) & IBEX35 (Spain) \\
\hline CAC40 & 1 & & & & \\
\hline DAX & 0.9332 & 1 & & & \\
\hline ISEQ & 0.7619 & 0.7093 & 0.7097 & \\
\hline FTSEMIB & 0.9171 & 0.8633 & 0.6900 & \\
\hline IBEX35 & 0.8926 & 0.8350 & 0.8880 & \\
\hline
\end{tabular}

Notes: All the correlation coefficients are significantly different from zero. Source: Own calculations.

Let us now turn to analysis of contagion from Ireland's, Italy's, and Spain's stock markets to the stock market of Germany (Figure 2). Notably, the start of Greece's debt crisis again coincides with the contagion from the stock markets of Ireland, Italy, and Spain to the stock market of Germany. Further episodes of contagion from Ireland's to German stock markets can be identified before the start of the Middle East financial crisis, at the start of 2007, and around the start of Ireland's debt crisis.

Contagion from Italy's and Spain's to German stock market took place also around the global financial crisis. Further episodes of contagion from Italy's and Spain's to German stock market can be noticed in the second half of 2005, at the end of 2006 (from Spain to Germany) or the start of 2007 (from Italy to Germany), around the start of Greece's, and after the start of Ireland's debt crisis.

The dynamics of returns of France's and German stock markets is not just the most correlated on average (see the Pearson's correlation calculated for the whole observed period in Table 2) but also exhibits the least volatile timepath among the pair-wise observed stock markets (see Figure 3). The correlation of returns between these two stock markets dropped below 0.8 just in year 2007 . Although the Forbes-Rigobon's adjusted moving-window correlation demonstrates a high integration of the two stock markets, clearly there were periods when correlation between the stock markets of these two countries significantly increased (z-statistics higher than 2), and thus can be associated with a contagion as defined in this paper. These periods were at the start of 2007, the start of the global financial crisis, the start of Greece's debt crisis, after the start of Ireland's debt crisis, and the start of Italy's debt crisis.

The results of this paper confirm the findings of other studies that shift contagion has played a role in the propagation of financial shocks during the crises (Bae et al., 2003; Corsetti et al., 2005; Bekaert et al., 2005;
Dungey \& Martin, 2007; Candelon et al., 2005; Rodriguez, 2007; Baur \& Lucey, 2009; Candelon \& Manner, 2010; Metiu, 2011) and have important implications for stock market investors. Since the seminal works of Markowitz (1958) and empirical evidence of Grubel (1968) it has been recognized that the total risk of internationally diversified portfolio can be reduced as a result of less than perfect comovement between returns of the portfolio assets. Increased co-movement between asset returns therefore can diminish the advantage of internationally diversified investment portfolios. The present analysis proves that this usually occurred in the crisis periods. The contagion analysis is also important for supervisory authorities because of their implications for the stability of financial markets, and for the central banks in conducting monetary policy (Clare \& Lekkos, 2000; Berben \& Jansen, 2005). 


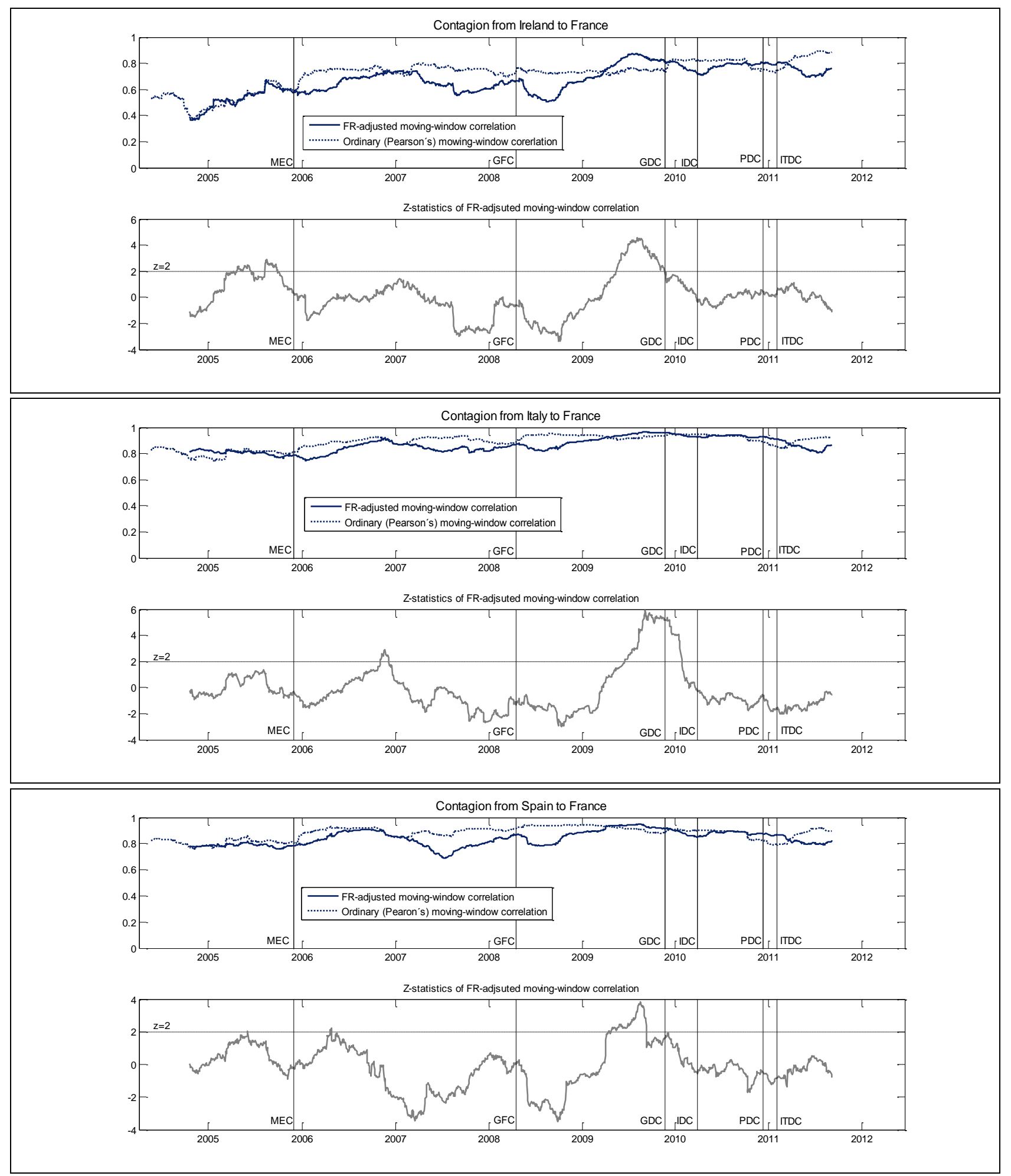

Figure 1. Contagion from the stock markets of Ireland, Italy, and Spain to the stock market of France

Notes: The Forbes-Rigobon (FR) adjusted moving window correlation time series is 100 observations shorter than the ordinary (Pearson's) movingwindow correlation due to characteristics of computation of the former. On the time axis, the financial market turmoil events are denoted: Sep11 = the September 11 attack on the WTC (September 11, 2001), IBB = the internet bubble burst (May 21, 2002 is denoted, when the Dow Jones Industrial reached its peak), $M E C=$ the Middle East financial markets crash (the start of May 2006 is denoted), GFC = the global financial crisis (September 16, 2008, the collapse of Lehman Brothers, is denoted), GDC = Greek debt crisis (April 23, 2010, when the Greek government requested a bailout from the EU/IMF is denoted), IDC = Ireland's debt crisis (September 1,2010, when the Irish government started negotiations for a bailout with the ECB/IMF is denoted), PDC = Portugal's debt crisis (May 16, 2011 is denoted, when Eurozone leaders approved a bailout of financial help for Portugal). The vertical lines, denoting financial turmoil events, are drawn 100 days (half the window length of the modified Forbes and Rigobon's adjusted correlation estimate) before the actual date of the event, as due to the construction characteristics of the moving-window correlation coefficients, the effect of the event should start to show up in the graph 100 days before the actual time of the event. The vertical lines are therefore drawn 100 days before the actual event. Critical values for the rejection of the null hypothesis (i.e. there is no significant increase in the modified Forbes and Rigobon's adjusted correlation) are denoted in the second sub-plots by the dotted horizontal lines at values $z=2(p=0.0228)$. Source: Own calculations. 

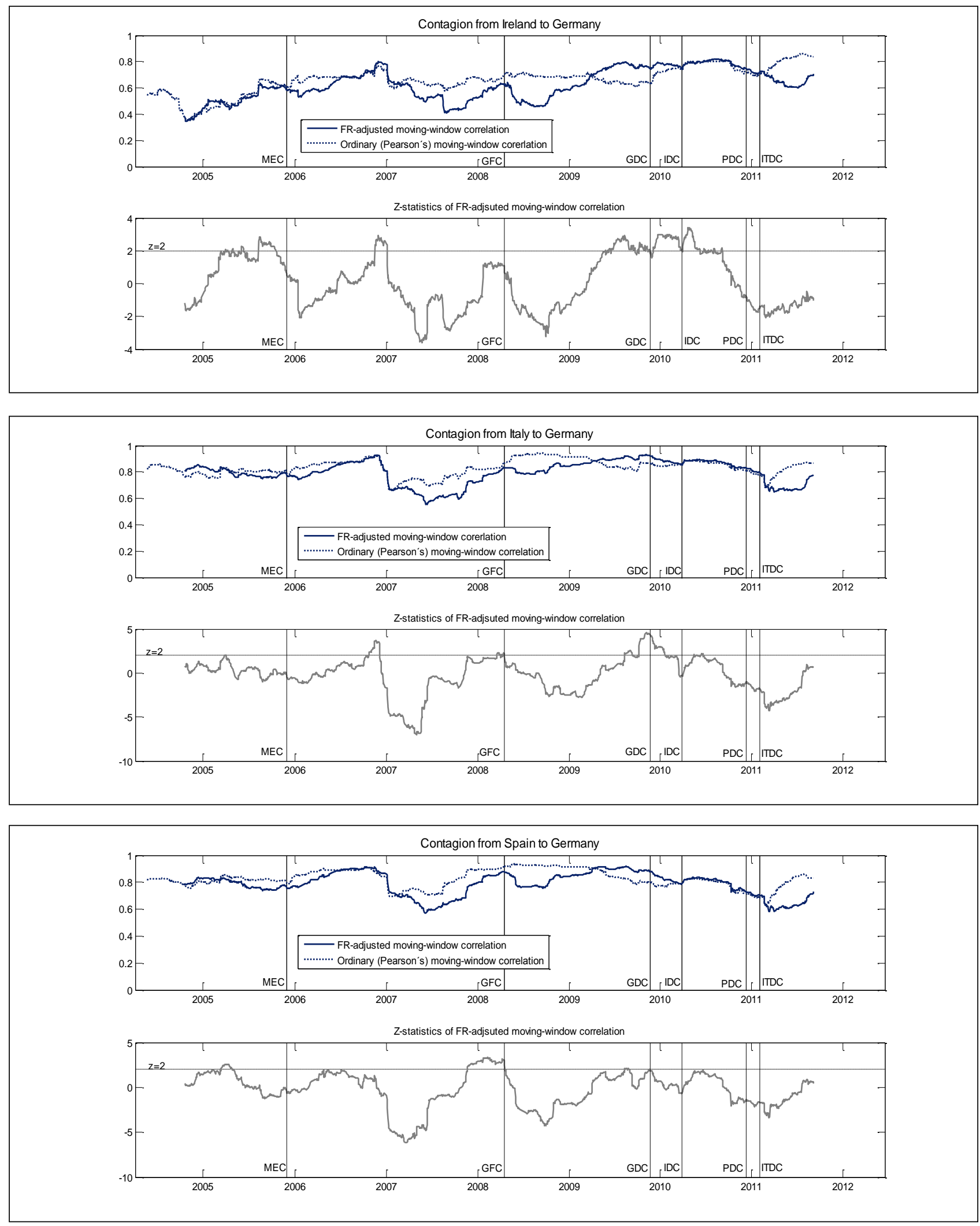

Figure 2. Contagion from the stock markets of Ireland, Italy, and Spain to the stock market of Germany

Note: See notes for Figure 1.

Source: Own calculations. 


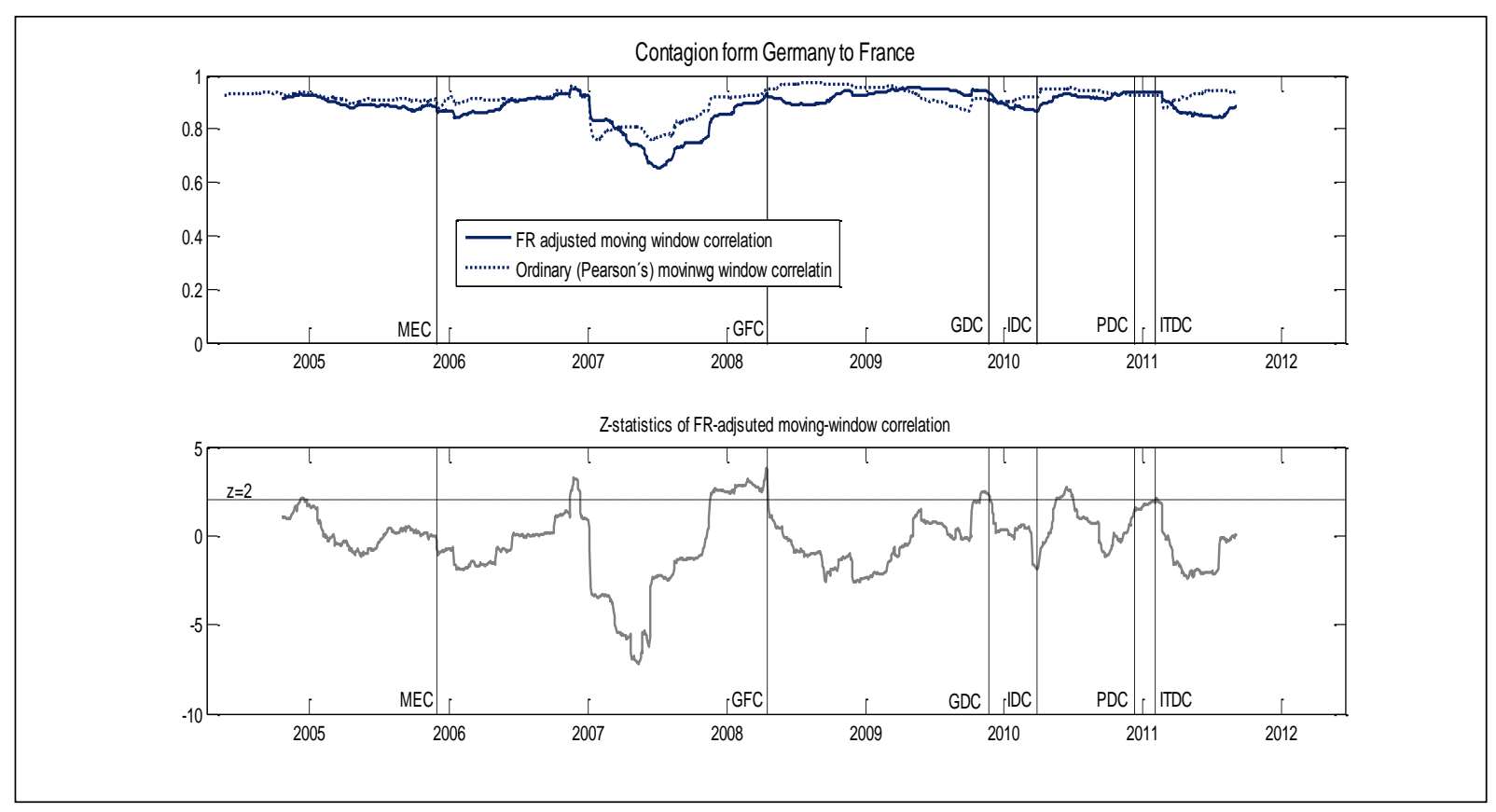

Figure 3. Contagion from the stock markets of Germany to the stock market of France

Note: See notes for Figure 1.

Source: Own calculations.

\section{Conclusions}

In this paper we applied the definition of shift contagion of Forbes and Rigobon (2001) and a modification of their adjusted correlation test to examine whether there was a (shift) contagion in the stock markets of five Eurozone countries (namely France, Germany, Ireland, Italy, and Spain) in the period from December 3, 2003 to January 27, 2012. Contagion was investigated for pair-wise observed stock markets returns where the source countries of contagion are taken to be the stock markets of Ireland, Italy, and Spain and the recipient countries (those to which contagion potentially spilled-over) the stock markets of France and Germany. We argue that the adjusted correlation test of Forbes and Rigobon has some statistical weaknesses that have to be considered in the contagion analysis. Particularly, we addressed the issues of crisis period identification - in the Forbes and Rigobon's method this is defined subjectively, thus causing a sample selection bias - and the issue of volatility adjustment. To achieve this, a moving-window approach of Forbes and Rigobon's (2002) method is proposed, by splitting the moving-window into two equally sized sub-windows. By this method, the crisis periods are identified endogenously by the date.

We found that the correlation of stock market returns in time-varying, with significant increases as well as significant drops in correlation. The correlation between pair-wise observed stock markets increased from the start of 2004 until the start of 2007, then dropped and rose again in the period from the mid 2008 until the second half of 2009 when the concerns about the sustainability of Greece's sovereign debt triggered an increase in risk aversion in the Eurozone's stock markets.
The start of Greece's debt crisis in May 2010 coincided with contagion from Ireland's, Italy's, and Spain's stock markets to the stock markets of France and Germany. Similar episodes of contagion were indentified around the Middle East financial crisis, at the end of 2006 and the start of 2007. The global financial crisis coincides with contagion from Italy's and the Spain's stock markets to German stock market, while Ireland's debt crisis coincides with contagion from Ireland's to German stock market. Several other periods of contagion from Ireland's, Italy's, and Spain's stock markets to the stock markets of France and Germany were also identified.

Three main conclusions may be drawn from the research. Firstly, the results of this paper confirm the findings of other studies that shift-contagion has played a role in the propagation of financial shocks during the major financial crises in the investigated time period. Secondly, this finding has important implications for the risk management and portfolio management as the benefits of international diversification are reduced when contagion in stock markets occurs. Identification of contagion in stock markets is also important for the supervisory authorities and the monetary policy as different policy actions may be successful when the increase in co-movement between financial markets is a result of contagion or a result of a change in interdependence between the markets. Thirdly, as a sample selection bias can occur in determination of a crisis period in the Forbes and Rigobon's method of contagion analysis, a method should be used that endogenously determines the crisis periods. 


\section{References}

Bae, K. H., Karolyi, G. A., \& Stulz, R. M. (2003). A New Approach to Measuring Financial Contagion. Review of Financial Studies, 16(3), 717-763. http://dx.doi.org/10.1093/rfs/hhg012

Baur, D. G., \& Lucey, B. M. (2009). Flights and Contagion - An Empirical Analysis of Stock-Bond Correlations. Journal of Financial Stability, 5(4), 339-352. http://dx.doi.org/10.1016/j.jfs.2008.08.001

Bekaert, G., Harvey, C. R., \& Ng, A. (2005). Market Integration and Contagion. Journal of Business, 78(1), 39-69. http://dx.doi.org/10.1086/426519

Berben, R. P., \& Jansen W. J. (2005). Bond Market and Stock Market Integration in Europe. Working Paper, No. 60, DNB - De Nederlandsche Bank.

Candelon, B., Hecq, A., \& Verschoor, W. F. C. (2005). Measuring Common Cyclical Features During Financial Turmoil: Evidence of Interdependence Not Contagion. Journal of International Money and Finance, 24(8), 1317-1334. http://dx.doi.org/10.1016/j.jimonfin.2005.08.011

Candelon, B., \& Manner, H. (2010). Testing for Contagion: A New Time-Varying Copula Approach. Pacific Economic Review, 15(3), 364-384. http://dx.doi.org/10.1111/j.1468-0106.2010.00508.x

Cho, J. H., \& Parhizgari, A. M. (2008). East Asian Financial Contagion Under DCC-GARCH. International Journal of Banking and Finance, 6(1), 16-30.

Clare, A., \& Lekkos, I. (2000). Decomposing the Relationship between International Bond Markets. Working Paper No. 123, Bank of England.

Corsetti, G., Pericoli, M., \& Sbracia, M. (2002). Some Contagion, Some Interdependence - More Pitfalls in Tests of Financial Contagion. Discussion Papers, No. 3310, C.E.P.R.. http://dx.doi.org/10.1016/j.jimonfin.2005.08.012

Corsetti, G., Pericoli, M., \& Sbracia, M. (2005). Some Contagion, Some Interdependence: More Pitfalls in Tests of Financial Contagion. Journal of International Money and Finance, 24(8), 1177-1199.

Dajcman, S., Festic, M., \& Kavkler, A. (2012). Comovement Dynamics between Central and Eastern European and Developed European Stock Markets during European Integration and Amid Financial Crises - A Wavelet Analysis, Inzinerine Ekonomika-Engineering Economics, 23(1), 22-32.

Dornbusch, R., Park, Y. C., \& Claessens, S. (2001). Contagion: Why crises spread and how this can be stopped, in International Financial Contagion (Eds) Claessens, S., and Forbes, K., New York: Springer, 19-42.

Dungey, M., Fry, R., Gonazles-Hermosillo, B., \& Martin, V. L. (2005) Empirical Modelling of Contagion: A review of Methodologies, Quantitative Finance, 5(1), 9-24. http://dx.doi.org/10.1080/14697680500142045

Dungey, M., \& Martin, V. L. (2007). Unraveling Financial Market Linkages During Crises. Journal of Applied Econometrics, 22(1), 89-119. http://dx.doi.org/10.1002/jae.936

Engle, F. R., \& Sheppard, K. (2001). Theoretical and Empirical Properties of Dynamic Conditional Correlation Multivariate GARCH, Working Paper No. 8554, NBER.

Favero, C. A., \& Giavazzi, F. (2002). Is the International Propagation of Financial Shocks Non-linear? Evidence from the ERM. Journal of International Economics, 57(1), 231-46. http://dx.doi.org/10.1016/S0022-1996(01)00139-8

Forbes, K. J., \& Rigobon, F. (2001). Measuring Contagion: Conceptual and Empirical Issues. in International Financial Contagion (Eds) Claessens, S., and Forbes, K., New York: Springer, 43-66. http://dx.doi.org/10.1007/978-1-47573314-3_3

Forbes, K., \& Rigobon, R. (2002). No Contagion, Only Interdependence: Measuring Stock Market Co-movements, Journal of Finance, 57(5), 2223-61. http://dx.doi.org/10.1111/0022-1082.00494

Gravele, T., \& Morley, J. (2006). Detecting Shift-Conftagion in Currency and Bond Markets. Journal of International Economics, 28(2), 409-423. http://dx.doi.org/10.1016/j.jinteco.2005.07.005

Grubel, H. (1968). Internationally Diversified Portfolios: Welfare Gains and Capital Flows, American Economic Review, 58(5), 1299-1314.

Markowitz, H. (1952). Portfolio Selection, Journal of Finance, 7(1), 77-91.

Metiu, N. (2011). Financial contagion in developed sovereign bond markets. METEOR - Maastricht Research School of Economics of Technology and Organization, Research Memoranda 004. Available from internet: http://edocs.ub.unimaas.nl/loader/file.asp?id=1574.

Pericoli, M., \& Sbracia, M. (2003). A Primer on Financial Contagion. Journal of Economic Surveys, 17(4), 571-608. http://dx.doi.org/10.1111/1467-6419.00205

Pesaran, H., \& Pick, A. (2003). Econometric Issues in the Analysis of Contagion, Working Paper No. 1176, CESifo.

Ranta, M. (2010). Wavelet Multiresolution Analysis of Financial Time Series, Paper No. 223, Acta Wasaensia.

Rodriguez, J. C. (2007). Measuring Financial Contagion: A Copula Approach, Journal of Empirical Finance, 14(3), 401423. http://dx.doi.org/10.1016/j.jempfin.2006.07.002 
Silvo Dajeman

Forbes ir Rigobon plitimo analizės metodo su endogeniškai apibrèžtais krizės laikotarpiais pritaikymas, kai kuriose euro zonos fondų biržose Santrauka

Forbes ir Rigobon (2001) pateike vieną iš tinkamiausiu „permainų plitimo“ apibrèžimų. Tai permainų arba pokyčių, kaip sukrètimų plitimas iš vienos šalies (arba turto klasès) i kitą prieš krizę, krizès laikotarpiu ir po krizės. „Permainų plitimas“ šiame darbe yra apibrež̌iamas kaip reikšmingas, teigiamas koreliacijos tarp fondų biržos apyvartos (poriniuose stebèjimuose) padidèjimas krizès laikotarpiu lyginant su nekriziniu laikotarpiu.

Egzistuoja keletas klausimu, susijusiu su Forbes ir Rigobon plitimo testu (2002), kuriuos reiktı̨ naujai pasiaiškinti. Pirmasis klausimas, kuris yra nepakankamai išaiškintas yra vienalaikiško šališkumo klausimas, kuris neatskleidžia galimų silpnų vietų kompromisų atveju. Dungey ir kt. (2005) i̇rodo, kad Forbes ir Rigobon testas (2002) turi polinkị i vienalaikiškq šališkumq tais atvejais, kai testas yra atliekamas keičiant kilmès šalies ekzogeniškumo statusą.

Kitas klausimas, susijęs su krizès laikotarpio apibrěžimu Forbes ir Rigobon teste (2002) apibrèžiamas subjektyviai, remiantis išankstine informacija apie ivykius, vykstančius prieš pat krizę. Tokiu būdu pavyzdys pasirenkamas šališkai. Trečiasis klausimas dèl Rigobon ir Forbes testo (2002), kuris turètų būti persvarstytas, yra tai, kad jis nereguliuoja kintamumo nuolat. Vadinasi, nepriima fakto dèl stilizuoto turto apyvartos kintamumo per tam tikrą laiką.

Šiame darbe nagrinèjamas ,,permainu plitimas“ penkių euro zonos šalių (Prancūzijos, Vokietijos, Airijos, Italijos ir Ispanijos) fondų biržose nuo 2003 metų gruodžio 3 d. iki 2012 metų sausio 27 d. Tyrime daugiausia dèmesio skiriama siekiant nustatyti ar permainos plito iš fondų biržų, kurias labiausiai paveike paskutinè 2010-2012 metų laikotarpio valstybių skolų krizè euro zonoje (Airijos, Italijos ir Ispanijos), i dvi svarbiausias euro zonos fondų biržas: Prancūzijos ir Vokietijos. Buvo pasiūlyta Forbes ir Rigobon (2002) testo modifikacija, pagrista ,judančio lango“ metodu, kuris endogeniškai nustato krizių laikotarpių datas ir atkreipia dèmesị i nepastovumo koregavimo klausimą.

Rezultatai rodo, kad fondų biržų apyvartos koreliacija kinta tam tikru laiku: labai padidẻja arba labai nukrenta. Koreliacija tarp poromis stebètų fondų biržų didèjo nuo 2004 metų pradžios iki 2007 metų pradžios, po to nukrito ir vèl išaugo nuo 2008 metų vidurio iki antrosios 2009 metu pusés, kai susirūpinimas dẻl Graikijos valstybès skolos euro zonos fondų biržose padidino rizikos baimę.

„Permainu plitimas“ atliko svarbų vaidmeni daugèjant sukrètimų nagrinèjamose fondų biržose krizių metu. Mes sužinojome, kad Graikijos skolų krizès pradžia 2010 metu gegužès mẻnesị sutapo su plitimu iš Airijos, Italijos ir Ispanijos fondų biržų i Prancūzijos ir Vokietijos fondų biržas. Panašus plitimo epizodas buvo nustatytas prieš Artimujų Rytų finansinę krizę 2006 metu pabaigoje arba 2007 metų pradžioje. Pasaulinè finansinè krizè sutapo su plitimu iš Italijos ir Ispanijos fondų biržu i Vokietijos fondų biržą, o Airijos skolų krizè sutapo su plitimu iš Airijos i Vokietijos fondų biržą.

Prancūzijos ir Vokietijos fondų biržų apyvartos dinamika yra ne tik geriausiai vidutiniškai koreliuota, bet taip pat rodo mažiausią kintamumą per tam tikrą laiką, tarp poromis stebètų fondų biržų. Vien tik per 2007 metus apyvartos koreliacija tarp šiu dvieju fondų biržu nukrito žemiau 0.8. Nors Forbe ir Rigobon suderinta ,judančių langu““ koreliacija atskleidžia aukštą dviejų fondų biržu integracija, yra aišku, kad buvo laikotarpių, per kuriuos koreliacija tarp šių dviejų šalių fondų biržų labai padidejo. Tai gali būti siejama su „,permainų plitimu“. Tokie laikotarpiai buvo 2007 metų pradžioje. Tai pasaulinès finansinès krizès pradžia, Graikijos skolų krizès pradžia, po to Airijos skolų krizės pradžia ir Italijos skolu krizès pradžia.

Iš šio tyrimo galima padaryti tris pagrindines išvadas. Pirmiausia, šio darbo rezultatai patvirtina kitu tyrimų rezultatus, kad „permainų plitimas“ atliko vaidmeni plečiantis finansiniams sukrètimams svarbiausių finansinių krizių laikotarpiais tiriamuoju laikotarpiu. Antra, šie rezultatai yra svarbūs rizikai ir portfeliui valdyti, nes tarptautinès diversifikacijos nauda sumažèja plitimo laikotarpiu. Plitimo fondu biržose nustatymas taip pat yra svarbus kontroliuojančioms institucijoms ir monetarinei politikai, nes skirtingi politikos veiksmai gali būti sèkmingi, kai bendro judejimo tarp finansinių rinku didejjimas yra plitimo rezultatas arba rinkų nepriklausomybès pokyčių rezultatas. Trečia, kadangi nustatant krizės laikotarpi Forbes ir Rigobon plitimo analizės metodu gali atsirasti pavyzdžio pasirinkimo šališkumas, reikètų naudoti tokị metodą, kuris endogeniškai nustatytų krizès laikotarpius.

Raktažodžiai: plitimas, fondu birža, finansinè krizè, euro zonos skolu krizé, pasauliné finansinè krizè.

The article has been reviewed.

Received in March, 2012; accepted in October, 2013. 